\title{
Ismertetés: Az egészség kulturális kontextusban: a narratív kutatás egészségügyi szektorbeli alkalmazása
}

\author{
Cultural contexts of health: the use of narrative research \\ in the health sector
}

Ismerteti: $\quad$ Csáki József Máté $\square$

Eötvös Loránd Tudományegyetem, Társadalomtudományi Kar

Szerző: Trisha Greenhalgh

Megjelenés: Health Evidence Network synthesis report 49 Copenhagen: WHO Regional Office for Europe; 2016 http://www.euro.who.int/_data/assets/pdf_file/0004/317623/HEN-synthesis-report49.pdf

Beküldve: 2018. 04. 12.

doi: 10.24365/ef.v59i3.279

Kulcsszavak: elbeszélés; kutatástervezés; kultúra; egészségügyi ellátás; egészségpolitika

Keywords: narration; research design; culture; delivery of health care; health policy

\section{BEVEZETÉS}

Az Egészségügyi Világszervezet (WHO) Európai Regionális Irodája az Egészség 2020 elnevezésű program keretében olyan egészségpolitikai változásokat szeretne eszközölni, amelyek elősegítik az egészségügyi rendszerek emberközpontúbb múködését. Ennek szellemében azt javasolja, hogy a hagyományos epidemiológiai, kvantitatív megközelítést, amely mérhető eredményekkel szolgál, egészítsék ki narratív kutatással.

Trisha Greenhalgh jelentése ${ }^{1}$ feltérképezi annak lehetséges módjait, hogy miképpen lehet integrálni a narratívát mint az emberi jelentéstulajdonítás rögzítőjét az egészségpolitikai tervezésbe. Az egészségügyben narratív megközelítésben végzett korábbi kutatások ismertetése során választ ad olyan, a módszer megbízhatóságával és érvényességével kapcsolatos kérdésekre, melyek az ilyen jellegú kutatások során gyakran felmerülnek. E módszertani megfontolások hamar érthetővé válnak olyan konkrét példákon keresztül, amelyek esettanulmányok és interjúk elemzése közben tûnnek elő, megvilágítva az egészség kulturális meghatározottságát. A narratív kutatás mint események szubjektív leírásának elemzése szigorú módszertani előírásokkal kell hogy rendelkezzék ahhoz, hogy megfelelő kiterjesztése legyen más, konvencionálisan objektívnak tekintett eredményeknek. A történetek elbeszélői szemszögét megjelenítő, és közben kutatás-módszertanilag helytálló elemzés mikéntjét három, jelentős mértékben kultúrafüggő jelenségeket leíró esettanulmányon keresztül ismerteti, amelyek alanyai egészségügyi ellátásra szorultak. Az ellátás során a szakemberek és a páciensek között felmerülő ellentéteket az egészséggel kapcsolatos eltérő felfogásaik okozhatják. Ugyanazokon a kulturális tételeken osztozó társadalmon belül is ellentmondás léphet fel a laikusok és a szakemberek elgondolásai között az egészséges étkezésről és magukról az egészség koncepcióját felépítő elemekről. Erről az első két esettanulmány ad számot. A kultúraközi egészségfelfogások pedig egyértelműen még ellentétesebbek; az ellentét mérséklésének lehetséges módjait a harmadik 
esettanulmány méri fel. A narratív kutatás segítheti az epidemiológiai tendenciák mögött meghúzódó folyamatok mélyebb megértését, feltéve, hogy az elemzést narratív módszertanból képzett szakember végzi.

\section{NARRATÍV KUTATÁS AZ EGÉSZSÉGÜGYBEN}

Egy 2014-es jelentés szerint ${ }^{2}$ a kulturális előfeltevések szerves részét képezik az orvosi gyakorlatnak csakúgy, mint a természettudományos és epidemiológiai felfedezések, s így jelentős figyelmet kellene fordítani az egészségügyi ellátás és az egészségkultúra összeegyeztetésére. Ennek előfeltétele a kultúra és az egészség metszetében zajló folyamatok megismerése narratív kutatáson keresztül. Az elbeszélt történetek valós eseményekről adnak számot, de szubjektivitás és egyedülálló értelmezés jellemzi őket. Tágabb kontextusban az egyéni értelmezés a társadalmi tényezők által befolyásolt, kulturálisan közös módon elvégzett értelmezés része, interszubjektív, vagyis az emberek szubjektív értékelései között számos egyezés található. A szubjektivitás különböző szintjei óvatosságra intenek a történetek kutatási célra való felhasználásakor. A narratív kutatás a megismerés megfelelő módja lehet, ha az adatgyújtés- és értelmezés módszeresen, fókuszáltan folyik, egy egyén vagy egy csoport adott eseményről való visszaemlékezése értelmezésének kifejezett céljával, feltárva az adott elbeszélésmód, narratíva felemelkedésének okait.

A szigorú kvalitatív-narratív kutatás a következőképpen írható le: a felületes vizsgálódást túllépve részletes elemzésre törekszik; hitelesen adja vissza a kutatási alanyok elbeszélését; önreflexív módon megkérdőjelezi saját eredményeit, és az értelmezés alternatív módjait keresi. A narratív kutatás elemzésének tárgya a történet, amely események feldolgozásában, megértésében, tényezői közötti ok-okozati összefüggések felállításában segíti a társadalmi cselekvóket. A történet rejtett kapcsolatokra világít rá a tudás rendszerezett, formális típusai és a „mindennapi”, informális típusai között. Etikai dimenziójuk rangsort állít fel a történet szereplői között, amelynek alján a hátrányos helyzetű, a beteg, az alapvető egészségügyi szolgáltatásokhoz hozzáférni képtelen cselekvő áll.
A megismerést lehetségesen torzító tényezők semlegesítéséhez széles körű kvalitatív módszertani ismeretekre van szükség. Az elbeszélők eltérő társadalmi, gazdasági és kulturális helyzete miatt a narratívák alkotásának képessége egyenlőtlenül oszlik meg közöttük, így rendszerint a legelőnyösebb státuszúak azok, akik a lehető legjobban tudják érvényre juttatni világlátásukat, mivel aránytalanul nagyobb valószínúséggel jelennek meg a kutatási mintákban. A narratívákat torzíthatják intézményes tényezők, átadásukat pedig részben vagy teljes egészében ellehetetleníthetik az elbeszélők fiziológiai vagy kognitív korlátai, ami a módszertani ismeretek körültekintő alkalmazására int. Fontos minimalizálni a mintanagyság és az elemzés mélységének ellentétéből fakadó torzítást, hiszen a nagyobb minta a narratívák felületes elemzését teszi csak lehetővé. A legtöbb félig strukturált - azaz előre megírt kérdések alapján folytatott - interjúval szemben a narratív interjúban a beszélgetés folyamatának bármiféle szerkesztése mellőzendő, aminek szintén előfeltétele a kvalitatív kutatási tapasztalat. A narratív kutatás kifejezetten hasznosnak bizonyul az egészségpolitikai tervezés során a kulturális komponensekre való érzékenység kialakításában, ha biztosított a színvonalas kvalitatív kutatáshoz szükséges képzettség. Az egyének szintjén az egészségtudatosság elbeszélésekkel való hangsúlyozása jobban felkeltheti az érdeklődést, mint a tudományos tényközlés, hiszen egy történettel azonosulni tudnak. A társadalom szintjén a narratív kutatás képes rávilágítani az egészségtelen életstílust okozó gazdasági és kulturális okokra.

\section{A JELENTÉS ÁLTAL VIZSGÁLT KÉRDÉSKÖRÖK}

Az első esettanulmány a táplálkozás kulturális aspektusaival foglalkozik. Különböző tanulmányok túzik ki az egészségpolitika hosszú távú céljának a járványszerűen terjedő, nem fertőző betegségek (cukorbetegség, rákos megbetegedések, köszvény, agyvérzés stb.) megfékezését, táplálkozáspolitikával való összefüggésében. ${ }^{3,4}$ Ez a megközelítés a táplálkozás két kultúrájának koncepciójában ${ }^{5}$ aránytalanul nagy hangsúlyt fektet az étel lenyelését követő (post-swallowing) síkra, az étel lenyelését megelőző síkkal (pre-swallowing) 
szemben. Ennek következtében az orvosi-kulturális (biológiai, fiziológiai, biokémiai, patológiai) meghatározottságú, táplálkozással kapcsolatos tudás háttérbe szorítja a kultúra, a társas érintkezések és a tapasztalatok által formált tudást. Utóbbi narratív kutatással térképezhető fel, segítve az emberek kulturálisan beágyazott táplálkozási szokásainak, az elhízásnak kedvező kulturális közeg elemeinek megismerését. Segít továbbá fontolóra venni a szegénység, az élelmiszer-bizonytalanság és a helyváltoztatás táplálkozásra gyakorolt hatásait. A szǔk látókörű megismerés figyelmen kívül hagyja, hogy az étkezéssel kapcsolatos tevékenységek társas indíttatásúak, történelmi és kulturális hagyományokra épülve. ${ }^{6,7}$ A táplálkozás különféle típusai (a templomi ostya lenyelése, McDonald's „happy meal”, közösségi étkezések, ünnepi étkezések stb.) szimbolikus és táplálkozási értékkel rendelkeznek, tükrözik és újratermelik a társadalmi szokásokat. ${ }^{8}$

A második esettanulmány az egészség különböző meghatározásait, egymás kiegészítésének lehetőségeit veszi számításba. A WHO egészségmeghatározása a következő: „Az egészség a teljes testi, szellemi és szociális jólét állapota, nem pusztán a betegség vagy fogyatékosság hiánya." ${ }^{9}$ Ebben a meghatározásban is látszik az igyekezet az egészség sokoldalú észleletének megragadására, különös tekintettel a gazdasági és a szociális helyzetre: a rossz egészségi állapot olyan társadalmi tényezőkkel magyarázandó, mint a szegénység, az oktatás, a lakhatás, a foglalkoztatás stb. Ez a felfogás összeköti az egészségpolitikát a társadalompolitikával, a társadalmi egyenlőtlenségek mérséklésével. ${ }^{10} \mathrm{Az}$ egészségfelfogás ilyen fajtái segíthetnek létrehozni a GDP-n kívül egyéb, a népesség általános egészségi állapotát leíró mérőszámokat, amelyek további értelmezését a narratív kutatás segítheti. Általuk megelőzhető például, hogy tovább terjedjen az egészségpolitikus szakemberek széles körében elfogadott prevenciós nézőpont, amely szerint az emberek egy igazgatandó tömeg tagjai, nem pedig tudással, értékekkel és értelemmel rendelkező, egészségükben érdekelt felek.
A harmadik példa arról szól, hogy miként ellensúlyozhatja a narratív módszer a pusztán mérőszámokon alapuló kutatások konvencionális objektivitását. ${ }^{11}$ Ezt példázzák azok a tapasztalatok, amelyek rávilágítanak a menekültek és a menedékkérők számára nyújtott egészségügyi ellátás hiányosságaira. A bevándorlók mentális egészségét befolyásolhatja többek között a kényszerû elvándorlás hatása, a pszichológiai és a kulturális beilleszkedéssel járó stressz, a menekültügyi és az egészségügyi rendszerben szerzett negatív tapasztalat stb. További esettanulmányokon ${ }^{12,13}$ keresztül megfigyelhető, hogy a kultúraközi különbségekből eredően a menekültek tapasztalatai nehezen fordíthatók le a nyugati pszichiátriai, orvosbiológiai és farmakológiai rendszertan fogalmaira. Továbbá a formális pszichiátriai diagnózisok nem veszik figyelembe a bevándorlók által elszenvedett elnyomás és diszkrimináció történelmi és kulturális metanarratíváit, azaz olyan általános narratívákat, amelyeken osztoznak egy csoport tagjai, és amelyekből kiindulva jelentést tulajdonítanak egyedi tapasztalataiknak.

\section{TANULSÁGOK A HAZAI SZAKEMBEREK SZÁMÁRA}

Megfontolandó az orvosbiológiai és az epidemiológiai kutatások kibővítése kulturális kontextusra érzékeny, narratív kutatásokkal, ami segítheti az egészségpolitika hatékonyabb, befogadóbb szemléletű szervezését. A narratív kutatási eredmények kiegészíthetik a klinikai vizsgálatok eredményeit, segíthetik az egyedülálló esetekből általános elmélet megfogalmazását, az induktív kutatások és a kérdőíves kutatások finomhangolását, magyarázattal szolgálhatnak a sikertelen egészségpolitikai kezdeményezésekre, illetve tájékoztatást nyújthatnak az egészségpolitikai döntés-előkészítők számára. A narratív kutatás hatékonyságának és megbízhatóságának záloga a kvalitatív kutatási eljárások területén képzett szakemberek alkalmazása. 


\section{HIVATKOZÁSOK}

${ }^{1}$ Greenhalgh T. Cultural contexts of health: the use of narrative research in the health sector. Copenhagen: WHO Regional Office for Europe; 2016 (Health Evidence Network (HEN) synthesis report 49).

http://dx.doi.org/10.24365/ef.v59i2.279

${ }^{2}$ Napier AD, Ancarno C, Butler B, et al. Culture and health. Lancet. 2014;384(9954):1607-39.

https://doi.org/10.1016/S0140-6736(14)61603-2

${ }^{3}$ Simopoulos AP, Bourne PG, Faergeman O. Bellagio report on healthy agriculture, healthy nutrition, healthy people. Nutrients. 2013;5(2):411-23. https://dx.doi.org/10.3390\%2Fnu5020411

${ }^{4}$ ICF Consulting Services for the Directorate-General for Health and Food Safety. Monitoring the activities of the EU platform on diet, physical activity and health. Luxembourg: Publications Office of the European Union; 2015. http://ec .europa.eu/health/nutrition physical activity/docs/eu platform 2015 report and annex1-3 en.pdf Elérve: 2018.05. 30.

${ }^{5}$ Huseinovic E, Winkvist A, Slimani N, et al. Meal patterns across ten European countries: results from the European Prospective Investigation into Cancer and Nutrition (EPIC) calibration study. Public Health Nutr. 2016:1-12. https://doi.org/10.1017/S1368980016001142

${ }^{6}$ Bell D, Valentine G. Consuming geographies: we are where we eat. London: Routledge; 1997. https://doi.org/10.1111/j.1745-7939.1997.tb00503.x

${ }^{7}$ Delormier T, Frohlich KL, Potvin L. Food and eating as social practice: eating patterns as social phenomena and implications for public health. Sociol Health III. 2009;31(2):215-28. https://doi.org/10.1111/j.1467-9566.2008.01128.x ${ }^{8}$ Douglas M. Food in the social order. London: Routledge; 1984.

${ }^{9}$ Constitution of WHO: principles. Geneva: World Health Organization; 1948. http://www.who.int/about/mission/en/ Elérve: 2018. 05. 30.

${ }^{10}$ Health 2020: the European policy for health and well-being. Copenhagen: WHO Regional Office for Europe; 2012. http://www.euro.who.int/en/health-topics/health-policy/health-2020-the-european-policy-for-health-and-well-being Elérve: 2018. 05. 30.

${ }^{11}$ Eastmond M. Stories as lived experience: narratives in forced migration research. J Refug Stud. 2007;20(2):248-64. http://dx.doi.org/10.1093/irs/fem007

${ }^{12}$ Summerfield D. My whole body is sick ... my life is not good. In: Ingleby D (editor). Forced migration and mental health. Rethinking the care of refugees and displaced persons. New York: Springer; 2005:97-114.

${ }^{13}$ Beneduce R. Traumatic pasts and the historical imagination: symptoms of loss, postcolonial suffering, and countermemories among African migrants. Transcult Psychiatry. 2016;53(3):261-85.

https://doi.org/10.1177/1363461516645079 